\title{
READING STRATEGIES USED BY VIETNAMESE EFL AND ESL UNIVERSITY STUDENTS
}

\author{
Nguyen Thi Bich Thuy* \\ College of Techniques, Economics and Trade, Phu Lam, Ha Dong, Hanoi, Vietnam
}

Received 2 January 2018

Revised 11 March 2018; Accepted 30 March 2018

\begin{abstract}
Reading comprehension is one of the most important factors in English language learning for all students because it is the basis of instruction in all aspects of language learning (Mikulecky, 2008). Comprehension is enhanced when the reader actively uses appropriate strategies in the reading process (Brown, 1980). This paper attempts to find out if there are any differences in the use of reading strategies between Vietnamese university students who learn English as a compulsory subject (EFL students) and those who use English as a means for their academic programs (ESL students) in their reading General English (GE) texts.
\end{abstract}

Keywords: reading, reading comprehension, reading strategies, EFL and ESL students

\section{Introduction}

Reading, as a receptive skill, has long been regarded as a prerequisite for foreign language acquisition (Aebersold \& Field, 1997) since it functions as an essential source of input for other skills (listening, speaking, and writing) to construct language proficiency. Being the essence of reading (Durkin, 1993), reading comprehension is one of the most important factors in English language learning for all students because it provides the basis for a substantial amount of learning in education (Alvermann \& Earle, 2003). Therefore, reading also plays a vital role in academic development, particularly when learners have to work over a huge amount of foreign language materials for their own specialist subjects (McDonough \& Shaw, 2013).

Students nowadays need not only to acquire knowledge and theories from English reading materials but also to read many English books, periodicals or magazines for the absorption of new knowledge and information. Strengthening English reading

${ }^{*}$ Tel.: 84-989125552

E-mail: bichthuy.ctet@gmail.com ability will be necessary for students to promote individual ability in competing. However, though students have to read a large volume of academic texts in English many of them entering university education are unprepared for the reading demands placed on them (Dreyer \& Nel, 2003). There are many factors affecting students' English reading proficiency such as text types, university and social environments, students' intelligence, learning motivation, teaching methods (Hsu, 2008), and one of the most important factors is students' use of reading strategies. The best prevention of reading difficulties is early intervention strategies (DeMoulin \& Loye, 1999), since second or foreign language readers can "compensate for a lack of English proficiency by invoking interactive strategies, utilizing prior knowledge, and becoming aware of their strategy choices" (Hudson as cited in Auerbach \& Paxton, 1997, p. 238).

However, in the reality of English teaching and learning, most students are unfamiliar with the utilization of English reading strategies. They show an inability to read selectively or to extract what is important for the purpose of reading and discarding what is insignificant. 
Also, they often select ineffective and inefficient strategies with little strategic intent (Wood, et al., 1998). Consequently, their reading comprehension is reduced. In their learning process, most students meet great challenges when dealing with reading texts. They usually do not understand texts and cannot complete the tasks so they feel tired and do not show enough interest in reading lessons or reading activities.

Being aware of the important role of reading in students' academic development the researcher conducted this research to find out if there are any differences in the use of reading strategies between Vietnamese university students who learn English as a subject (hereafter called EFL students) and those who use English as a means for their academic programs (hereafter called ESL students) in their reading General English (GE) texts.

The study aims to answer the following question: Are there any differences in the use of reading strategies between students who learn English as a compulsory subject and those who use English as a means for their academic study in their reading General English (GE) texts?

\section{Methodology}

\subsection{Instruments of the study}

Considering all the advantages and disadvantages of instruments applied in language learning strategy researching, Reading Strategy Questionnaire is the most preferably chosen for this study.

The questionnaire used in this study consists of two parts:

- Part One designed to gather the information about individual characteristics of the participants required the subjects to supply their ethnographic data, such as gender, age, time of English study, major, their self-assessment on English and reading proficiency, etc.

- Part Two included nineteen statements appropriate to nineteen different strategies applied in reading comprehension.

The nineteen statements were divided into four sections, corresponding to four strategy categories: Metastrategies, Cognitive strategies, Affective strategies, and Sociocultural Interactive strategies.

Metastrategy category consisting of eight strategies aimed to help readers manage and control the reading process in a general sense, with a focus on understanding readers' own needs and using and adjusting the other strategies to meet those needs, for example planning, organizing, monitoring, evaluating, etc.

Cognitive category included six strategies, which helped readers remember and process the reading process, such as activating knowledge, constructing, transforming, etc.

The third category namely Affective consisted of two strategies helped readers handle emotions, beliefs, attitudes, and motivation in their reading process.

The last strategy category was Sociocultural Interactive, which included three strategies, supported readers to deal with issues of contexts, communication, and culture in their reading comprehension.

These questionnaire statements, which are broad, teachable actions that readers choose from among alternatives and employ for second/foreign language learning purposes, were adopted from the S2R (Self-Strategic Regulation) strategy model by Oxford (2013).

The main reasons for the choice of this model is that self-regulation is one of the most exciting developments in second or foreign language learning (Oxford, 2013, p.7). In addition, Oxford's (2013) model focuses on factors that make learning easier, more enjoyable, faster, and more efficient. Specially, Oxford's (2013) S2R reading strategy classification shows its scientific elegance as it avoids the overlap of strategies in some other taxonomies. 
The internal reliability of the questionnaire was high with Cronbach's Alpha $=.855$ for 19 items of reading strategies. The external reliability of the questionnaire was also assured as all the nineteen items in the questionnaire were replicated from Oxford's (1990) Strategy Inventory for Language Learning (SILL) which has been applied by a number of other researchers across the world in the field (Kaylani, 1996; Oxford, 2001).

For each questionnaire statement, five alternative choices were provided. Participants were asked to select one from among the followings:

1 for Never or almost never true of me

2 for Usually not true of me

3 for Somewhat true of me

4 for Usually true of me

5 for Always or almost true of me

The higher the number that respondents indicated applied to them, the more frequent the use of the particular strategy was reflected. The whole questionnaire was translated into Vietnamese for the participants' better understanding.

\subsection{Subjects}

Two hundred and eighty-six students from University of National Economics and Academy of Banking majoring in Accounting and Finance participated in this study. Based on the purpose of the study, the participants were divided into two groups. Group one consisted of one hundred and twenty-two students who learned English as a subject at university and they used English as a foreign language (hereafter called EFL students). Group two included one hundred and sixty-four students who studied in advanced programs and used English as a means for their academic study at university (hereafter called ESL students). All of the participants were non-English majored second or third year students. EFL students had to study general English and professional English in their universities, of which general
English course took about 9-12 credits and English for specific purposes course took 3-4 credits. Meanwhile, ESL students did not study English in their curriculum. Since their academic programs were taught in English, they were required to have good enough English proficiency (usually IELTS $\geq 4.5$ or equivalent) when enrolling the universities.

\subsection{Procedures}

At the beginning of the procedures all of the participants were introduced to the purpose of the study and were explained that all information reported by them would be used for research purposes only. The main aim of using the strategy questionnaire was to draw out the types and frequency of use of reading strategies by the participants when they read EGAP texts. In addition, by requiring the participants to provide their ethnographic information, the researcher aimed to find out how the variables such as participants' gender, academic major, English learning time, self-rated English learning and English reading proficiency, etc., related to the students' English reading strategy use. The students then were given guidelines and instructions for completing the questionnaire. They were encouraged to ask the researcher for anything they did not understand or were not clear. The students then filled in the two parts of the questionnaire, which took about thirty to forty minutes.

\subsection{Data analysis}

The Statistical Package for the Social Science (SPSS) version 20.0 was used to analyze the data from questionnaires. An independent T-test and one way MANOVA were used to determine the frequency level of each strategy use between the two groups of students.

The types and frequencies of strategies used were counted and averaged by adding up individual scores from each participant 
to obtain a total score for each subscale in the strategy questionnaire (Metastrategies, Cognitive strategies, Affective strategies, and Socio-cultural Interactive strategies) and for the entire instrument. The scores for respective subscale were added up and divided by the number of items in each $(8$ items for Metastrategies, 6 for Cognitive strategies, 2 for Affective strategies, and 3 for Socio-cultural Interactive strategies). The higher the averages the more frequently the participants used the strategy concerned. The scores were interpreted in three levels with the interpretation key based on frequency scale delineated by Oxford (1990) for general learning strategy usage. The mean of 3.50 or higher shows high usage, the mean of 2.5 to 3.49 is medium usage and the mean of 2.49 or lower is low usage. The usage levels provided a convenient standard for interpretation of the score averages.

The differences in the overall use of reading strategies and strategy categories between the two groups were also revealed.

\section{Results and discussion}

\subsection{Strategies used by EFL and ESL students in reading comprehension}

An independent t-test was employed to analyze the data in this study. Regarding the total reading strategies, ESL students reported better use of reading strategies $(\mathrm{M}=3.11$; $\mathrm{S} . \mathrm{D}=1.032)$ than $\mathrm{EFL}$ readers $(\mathrm{M}=2.95$; $\mathrm{S} . \mathrm{D}=1.026)$. Statistical representation of the analyzed data is given in Tables 1 and 2 .

Table 1. Overall Strategy Use by EFL and ESL Students

\begin{tabular}{|c|c|c|c|}
\hline Group & Number & Mean & S.D \\
\hline EFL & 122 & 2.95 & 1.026 \\
\hline ESL & 164 & 3.11 & 1.032 \\
\hline
\end{tabular}

Table 2 shows the means and standard deviations of the dependent variables- the four reading strategy categories, for the two groups of participants. It can be seen from the table that ESL students outperformed those of the first group in the use of all the reading strategy categories except for Affective category.

Table 2. Strategy Use by Categories by EFL and ESL Students

\begin{tabular}{|c|c|c|c|c|}
\hline Category & Group & N & Mean & S.D \\
\hline \multirow{2}{*}{ Metastrategies } & EFL & 122 & 2.73 & 0.694 \\
\cline { 2 - 5 } & ESL & 164 & 2.80 & 0.629 \\
\hline \multirow{2}{*}{ Cognitive strategies } & EFL & 122 & 3.28 & 0.865 \\
\cline { 2 - 5 } & ESL & 164 & 3.63 & 0.817 \\
\hline \multirow{2}{*}{ Affective strategies } & EFL & 122 & 3.06 & 1.016 \\
\cline { 2 - 5 } & ESL & 164 & 2.94 & 0.913 \\
\hline \multirow{2}{*}{$\begin{array}{c}\text { Sociocultural } \\
\text { interactive strategies }\end{array}$} & EFL & 122 & 2.83 & 0.812 \\
\cline { 2 - 5 } & ESL & 164 & 2.97 & 0.847 \\
\hline
\end{tabular}

A one-way MANOVA was conducted to determine the effect of the characteristics of the two groups on the use of the four dependent variables. Significant differences were found between the two groups on the dependent measures, Wilks' $\lambda=0.934$, $\mathrm{F}(4,281)=4.957, \quad \mathrm{p}=0.001<0.005, \quad$ Partial Eta Squared $=.066$. This result indicates that characteristics of the groups were related to the way the participants used the four reading strategy categories.

For further examination, tests of between subject effects were conducted and the results are summarized in Table 3 below. It can be seen from the table that there were statistically significant differences in the use of only cognitive strategy category among students of the two groups with $p=0.001<0.05$. The results reveal that the use of cognitive strategies was significantly different between the two groups.

The scores of the use of each strategy by 
Table 3. Tests of between Subject Effects

\begin{tabular}{|c|c|c|c|c|c|c|c|}
\hline Source & Dependent Variable & $\begin{array}{c}\text { Type III Sum } \\
\text { of Squares }\end{array}$ & $\mathrm{df}$ & $\begin{array}{l}\text { Mean } \\
\text { Square }\end{array}$ & $\mathrm{F}$ & Sig. & $\begin{array}{c}\text { Partial Eta } \\
\text { Squared }\end{array}$ \\
\hline \multirow{4}{*}{ Group } & Metastrategies & 27.201 & 1 & 27.201 & .983 & .322 & .003 \\
\hline & Cognitive strategies & 304.930 & 1 & 304.930 & 12.071 & .001 & .041 \\
\hline & Affectivestrategies & 3.461 & 1 & 3.461 & .943 & .332 & .003 \\
\hline & $\begin{array}{c}\text { Sociocultural interactive } \\
\text { strategies }\end{array}$ & 13.496 & 1 & 13.496 & 2.164 & .142 & .008 \\
\hline \multirow{4}{*}{ Error } & Metastrategies & 7857.401 & 284 & 27.667 & & & \\
\hline & Cognitive strategies & 7174.328 & 284 & 25.262 & & & \\
\hline & Affective strategies & 1042.414 & 284 & 3.670 & & & \\
\hline & $\begin{array}{c}\text { Sociocultural interactive } \\
\text { strategies }\end{array}$ & 1771.231 & 284 & 6.237 & & & \\
\hline
\end{tabular}

students of the two groups were also analyzed and the results are presented in Table 4. The means for the use of individual strategies ranged from a high use of 3.48 to a medium of 2.4 for EFL students and from a high of 3.6 to a medium of 2.51 for ESL students. A closer examination of the top five strategies most used among students of each group showed that strategy "Activating Knowledge" had the highest average frequency and at high level for both groups $(\mathrm{M}=3.48$ and $\mathrm{M}=3.76$, respectively). Two other strategies which reported being used the most by the participants of both groups were "Using the Senses to Understand and Remember", and Going Beyond the Immediate Data" $(\mathrm{M}=3.28$, $\mathrm{M}=3.7 ; \mathrm{M}=3.28, \mathrm{M}=3.59$, respectively). Two more strategies which were also most used by EFL students were Obtaining and Using Resources $(\mathrm{M}=3.44)$ and Conceptualizing with Details $(\mathrm{M}=3.24)$, and those by EFL students were Reasoning $(\mathrm{M}=3.6)$ and Conceptualizing Broadly $(\mathrm{M}=3.59)$. Of the strategies reported using the most by EFL students, one belongs to Metastrategy category (Obtaining and Using Resources) and the other four belong to
Cognitive category. Meanwhile all strategies of the most used group by ESL students appear in the category of Cognitive strategies only.

It is noticeable that students of both groups shared the same five strategies of the lowest level of frequency, namely Planning, Organizing, Implementing Plans, Orchestrating Strategy Use, and Monitoring with $\mathrm{M}=2.48,2.51 ; 2.4,2.53 ; 2.49,2.55 ; 2.52$, 2.59; and 2.66, 2.7, respectively. All strategies of the lowest usage level fell into the category of Metastrategies.

Regarding the remaining strategies presented in Table 4, both groups showed a mixture of the four strategy categories. 
Table 4. Individual Strategies Used by EFL vs ESL Students

\begin{tabular}{|c|c|c|}
\hline \multicolumn{3}{|l|}{ EFL (122) } \\
\hline Strategies & Mean & S.D \\
\hline S10 Activating Knowledge & 3.48 & 1.054 \\
\hline $\begin{array}{l}\text { S3 Obtaining and Using } \\
\text { Resources }\end{array}$ & 3.44 & 1.084 \\
\hline $\begin{array}{l}\text { S9 Using the Senses to } \\
\text { Understand and Remember }\end{array}$ & 3.28 & 1.085 \\
\hline $\begin{array}{l}\text { S14 Going Beyond the } \\
\text { Immediate Data }\end{array}$ & 3.28 & 1.054 \\
\hline $\begin{array}{c}\text { S12 Conceptualizing with } \\
\text { Details }\end{array}$ & 3.24 & 1.053 \\
\hline S11 Reasoning & 3.23 & 1.043 \\
\hline S13 Conceptualizing Broadly & 3.2 & 1.073 \\
\hline $\begin{array}{c}\text { S15 Activating Supportive } \\
\text { Emotions, Beliefs, and } \\
\text { Attitudes } \\
\end{array}$ & 3.16 & 1.109 \\
\hline S1 Paying attention & 3.11 & 1.069 \\
\hline $\begin{array}{c}\text { S16 Generating and } \\
\text { Maintaining Motivation }\end{array}$ & 2.94 & 1.101 \\
\hline $\begin{array}{l}\text { S18 Overcoming Knowledge } \\
\text { Gaps in Communicating }\end{array}$ & 2.85 & 0.897 \\
\hline $\begin{array}{l}\text { S19 Dealing with Socio- } \\
\text { cultural Contexts and } \\
\text { Identities }\end{array}$ & 2.85 & 1.034 \\
\hline $\begin{array}{c}\text { S17 Interacting to Learn and } \\
\text { Communicate }\end{array}$ & 2.77 & 1.059 \\
\hline S8 Evaluating & 2.7 & 0.995 \\
\hline S7 Monitoring & 2.66 & 1.041 \\
\hline S6 Orchestrating Strategy Use & 2.52 & 0.989 \\
\hline S5 Implementing Plans & 2.49 & 1.038 \\
\hline S2 Planning & 2.48 & 0.964 \\
\hline S4 Organizing & 2.4 & 0.859 \\
\hline
\end{tabular}

Furthermore, a closer look at Table 4 indicates that seven of the nineteen strategies (36.8\%) reported by ESL students fell in the high use category $(\mathrm{M}=3.5$ or higher), twelve strategies $(63.8 \%)$ placed in the medium category of use ( $M=$ between 2.5 and 3.49). Conversely, EFL reported using none of the strategies at high level of frequency. Eighteen

\begin{tabular}{|c|c|c|}
\hline \multicolumn{3}{|l|}{ ESL (164) } \\
\hline Strategies & Mean & S.D \\
\hline S10 Activating Knowledge & 3.76 & 0.947 \\
\hline $\begin{array}{l}\text { S9 Using the Senses to } \\
\text { Understand and Remember }\end{array}$ & 3.7 & 0.973 \\
\hline S11 Reasoning & 3.6 & 1.032 \\
\hline S13 Conceptualizing Broadly & 3.59 & 1.008 \\
\hline $\begin{array}{l}\text { S14 Going Beyond the } \\
\text { Immediate Data }\end{array}$ & 3.59 & 1.056 \\
\hline $\begin{array}{l}\text { S12 Conceptualizing with } \\
\text { Details }\end{array}$ & 3.56 & 1.131 \\
\hline $\begin{array}{l}\text { S3 Obtaining and Using } \\
\text { Resources }\end{array}$ & 3.43 & 1.022 \\
\hline S1 Paying attention & 3.25 & 0.974 \\
\hline $\begin{array}{l}\text { S19 Dealing with Socio- } \\
\text { cultural Contexts and Identities }\end{array}$ & 3.08 & 0.933 \\
\hline $\begin{array}{c}\text { S16 Generating and } \\
\text { Maintaining Motivation }\end{array}$ & 2.99 & 0.959 \\
\hline $\begin{array}{l}\text { S18 Overcoming Knowledge } \\
\text { Gaps in Communicating }\end{array}$ & 2.98 & 1.085 \\
\hline $\begin{array}{c}\text { S15 Activating Supportive } \\
\text { Emotions, Beliefs, and } \\
\text { Attitudes }\end{array}$ & 2.9 & 1.06 \\
\hline S8 Evaluating & 2.86 & 1.073 \\
\hline $\begin{array}{l}\text { S17 Interacting to Learn and } \\
\text { Communicate }\end{array}$ & 2.86 & 1.14 \\
\hline S7 Monitoring & 2.7 & 1.028 \\
\hline S6 Orchestrating Strategy Use & 2.59 & 1.056 \\
\hline S5 Implementing Plans & 2.55 & 1.023 \\
\hline S4 Organizing & 2.53 & 0.987 \\
\hline S2 Planning & 2.51 & 1.006 \\
\hline
\end{tabular}

of the nineteen strategies were used at medium level ( $\mathrm{M}=$ from 2.48 to 3.48). One of the strategies was at low usage level by EFL group ( $M=2.4$ for Organizing).

In order to find out if there were any significant differences in the use of each reading strategy, another independent samples t-test for individual strategies was performed 
and the results are summarized in Table 5 . As indicated in the table, seven strategies in bold showed significant differences: Using the Senses to Understand and Remember $(\mathrm{p}=0.001)$, Activating Knowledge $(\mathrm{p}=0.25)$, Reasoning $(\mathrm{p}=0.03)$, Conceptualizing with Details $(\mathrm{p}=0.14)$, Conceptualizing Broadly $(\mathrm{p}=0.02)$, Going Beyond the Immediate Data $(\mathrm{p}=0.16)$, and Activating Supportive Emotions, Beliefs, and Attitudes $(\mathrm{p}=0.39)$. Of these seven strategies, ESL students reported to be better in using six strategies- Using the Senses to Understand and Remember, Activating Knowledge, Reasoning, Conceptualizing with Details, Conceptualizing Broadly, and Going Beyond the Immediate Data, meanwhile EFL students stated greater use in only one strategy-Activating Supportive Emotions, Beliefs, and Attitudes.

Table 5. Sample t-test of Individual Strategies Used between EFL \& ESL Students

\begin{tabular}{|c|c|c|c|c|c|c|c|}
\hline \multirow[t]{2}{*}{ Category } & \multirow[t]{2}{*}{ Strategies } & \multicolumn{2}{|c|}{$\begin{array}{c}\text { EFL } \\
(n=122)\end{array}$} & \multicolumn{2}{|c|}{$\begin{array}{c}\text { ESL } \\
(\mathrm{n}=164)\end{array}$} & \multirow[t]{2}{*}{$\mathbf{t}$} & \multirow[t]{2}{*}{ p-value } \\
\hline & & Mean & S.D & M & S.D & & \\
\hline \multicolumn{8}{|c|}{ Metastrategies } \\
\hline M1 & S1 Paying attention & 3.11 & 1.069 & 3.25 & 0.974 & -1.113 & .266 \\
\hline M2 & S2 Planning & 2.48 & 0.964 & 2.51 & 1.006 & -.311 & .756 \\
\hline M3 & S3 Obtaining and Using Resources & 3.44 & 1.084 & 3.43 & 1.022 & .077 & .938 \\
\hline M4 & S4 Organizing & 2.4 & 0.859 & 2.53 & 0.987 & -1.177 & .240 \\
\hline M5 & S5 Implementing Plans & 2.49 & 1.038 & 2.55 & 1.023 & -.512 & .609 \\
\hline M6 & S6 Orchestrating Strategy Use & 2.52 & 0.989 & 2.59 & 1.056 & -.561 & .575 \\
\hline M7 & S7 Monitoring & 2.66 & 1.041 & 2.7 & 1.028 & -.302 & .763 \\
\hline M8 & S8 Evaluating & 2.7 & 0.995 & 2.86 & 1.073 & -1.310 & .191 \\
\hline \multicolumn{8}{|c|}{ Cognitive strategies } \\
\hline $\mathrm{C} 1$ & $\begin{array}{l}\text { S9 Using the Senses to Understand and } \\
\text { Remember }\end{array}$ & 3.28 & 1.085 & 3.7 & 0.973 & -3.457 & .001 \\
\hline $\mathrm{C} 2$ & S10 Activating Knowledge & 3.48 & 1.054 & 3.76 & 0.947 & -2.257 & .025 \\
\hline $\mathrm{C} 3$ & S11 Reasoning & 3.23 & 1.043 & 3.6 & 1.032 & -2.970 & .003 \\
\hline $\mathrm{C} 4$ & S12 Conceptualizing with Details & 3.24 & 1.053 & 3.56 & 1.131 & -2.462 & .014 \\
\hline $\mathrm{C} 5$ & S13 Conceptualizing Broadly & 3.2 & 1.073 & 3.59 & 1.008 & -3.186 & .002 \\
\hline C6 & S14 Going Beyond the Immediate Data & 3.28 & 1.054 & 3.59 & 1.056 & -2.430 & .016 \\
\hline \multicolumn{8}{|c|}{ Affective strategies } \\
\hline A1 & $\begin{array}{c}\text { S15 Activating Supportive Emotions, } \\
\text { Beliefs, and Attitudes }\end{array}$ & 3.16 & 1.109 & 2.9 & 1.06 & 2.070 & .039 \\
\hline $\mathrm{A} 2$ & $\begin{array}{l}\text { S16 Generating and Maintaining } \\
\text { Motivation }\end{array}$ & 2.94 & 1.101 & 2.99 & 0.959 & -.370 & .712 \\
\hline \multicolumn{8}{|c|}{ Socio-cultural interactive strategies } \\
\hline S1 & $\begin{array}{l}\text { S17 Interacting to Learn and } \\
\text { Communicate }\end{array}$ & 2.77 & 1.059 & 2.86 & 1.14 & -.675 & .500 \\
\hline $\mathrm{S} 2$ & $\begin{array}{l}\text { S18 Overcoming Knowledge Gaps in } \\
\text { Communicating }\end{array}$ & 2.85 & 0.897 & 2.98 & 1.085 & -1.021 & .308 \\
\hline S3 & $\begin{array}{l}\text { S19 Dealing with Socio-cultural } \\
\text { Contexts and Identities }\end{array}$ & 2.85 & 1.034 & 3.08 & 0.933 & -1.912 & .057 \\
\hline
\end{tabular}


In sum, the major findings of the study can be summarized as follows:

- ESL students reported better use of reading strategies than EFL readers when they read general English academic materials. ESL students outperformed EFL students in the use of all the reading strategy categories except for Affective category. There were significant differences in the use of Cognitive strategies between the two groups.

- All strategies ESL students used the most appeared in the category of Cognitive strategies. Both ESL and EFL students shared the same five strategies of the lowest level of frequency and all these strategies belonged to Metastrategies.

\subsection{Discussion}

The results showed that generally, students of ESL group reported using reading strategies more frequently than those of EFL group $(\mathrm{M}=3.11 ; \mathrm{S} . \mathrm{D}=1.026$ for $\mathrm{ESL}$ and $\mathrm{M}=2.95 ; \mathrm{S} . \mathrm{D}=1.032$ for $\mathrm{EFL}$ ). This finding was consistent with Karbalaei's (2010) study when he found out that Indians as ESL learners reported better use of total reading strategies $(\mathrm{M}=3.16 ; \mathrm{SD}=.389)$ than Iranian as EFL learners $(\mathrm{M}=2.90 ; \mathrm{SD}=0.592)$.

One important factor should be mentioned here was that ESL students used seven of the nineteen strategies $(36,8 \%)$ at high level of frequency ( $\mathrm{M}=$ from 3.76 to 3.43 ) and all the other strategies were reported being used at medium frequency level $(\mathrm{M}=$ from 3.25 to 2.51). Meanwhile, eighteen of the nineteen strategies were used at medium frequency level by the students of the EFL group; one strategy was reported being used at low level ( $M=2.4$ for Organizing). So, it could be stated here that ESL students overwhelmed EFL students in the use of reading strategies both in the types of strategies and in the frequency level of use.

Concerning the use of reading strategy categories, ESL group reported selecting
Cognitive strategies as the most used category, followed by Socio-cultural Interactive and Affective strategies. EFL group also preferred Cognitive strategies, then Affective strategies and Socio-cultural Interactive strategies. Both groups showed the least usage level of Metastrategies. This result supports Karbalaei's (2010) and Tercanlioglu's (2004) studies when they both stated that both EFL and ESL college students reported choosing cognitive strategies as the most used strategies.

However, the statistical results showed a significant difference in the use of Cognitive strategies between the two groups. Students of the ESL group used strategies of this subscale mush more frequently than those of EFL group ( $\mathrm{M}=3.63$ and 3.28, respectively). This result was different from the study by Anderson (2003) when he conducted a research on two hundred and forty-seven ESL/EFL students in Utah and found out that students in EFL environment reported higher use of Problem Solving (Cognitive) strategies than those in ESL environment. He concluded that this was perhaps because the EFL/ESL distinction was diminishing. According to Anderson (2003), owing to radio, television, the Internet, and availability of good pedagogical materials learners of English around the world have increased opportunities for exposure to English, which provides increased opportunities for input in English and thus decreases the traditional EFL-ESL dichotomy. However, this might not suitable for the context of this study. The participants in this study were in different English using environments and the contexts seemed to affect their English reading comprehension efficiency. The EFL students were learning English as one of their compulsory subjects at university, while their counterparts used English as a means of their academic study. ESL students had to use English in their study and English reading ability certainly was 
the basic requirements for their academic course accomplishment. Therefore, the differences in the use of reading strategies by the participants of the two groups here might be caused by students' English learning motivation. The English requirements for ESL students required them a lot of efforts in their English learning. Specifically, the learning environment made ESL students read a lot in English, much more than EFL students, which forced them know how to read effectively and try to become strategic readers. Levels of motivation and engagement have been found to predict achievement and motivation is thought to be one of the most critical determinants of the success and quality of any learning outcome (Baker \& Wigfield, 1999). Baumann and Duffy (1997) state that "motivation to read and reading ability are synergistic, mutually reinforcing phenomena" (p.6). Better readers tend to read more because they are motivated to read, which leads to improved vocabulary and better skills. Therefore, reading motivation, which is defined as "the individual's personal goals, values and beliefs with regards to the topics, processes, and outcome of reading" (Guthrie et al., 2000) plays a very important role in the students' use of reading strategies.

Although there are no statistical differences in the use of Affective category between the two groups, there is a difference in the use of one item of this category Activating Supportive Emotions, Beliefs, and Attitudes. The figures also indicate that students of EFL group showed higher frequent use of this category than their counterparts ( $M=3.06$ for EFL and $\mathrm{M}=2.94$ for $E S L)$. This indicates EFL students were better in handling their emotions, beliefs, attitudes in reading than ESL participants. Affective factors, such as attitudes, motivation, anxiety, and selfesteem, have great influence on the success of language learning since 'the way we feel about our capacities and ourselves can either facilitate or impede our learning" (Arnold \& Brown, 1999, p. 8). In addition, Andres (2002) argues that "if we want our students to develop their inherent potential to learn, the affective variables such as anxiety, motivation, self-esteem and inhibition and the inner needs of the learners can no longer be neglected" ( $p$. 97). Furthermore, Affective strategies, such as identifying one's mood and anxiety level, talking about feelings, rewarding oneself for good performance, and using deep breathing or positive self-talk, have been shown to be significantly related to L2 proficiency in research (Magno, 2009). However, Oxford (2003) claims that affective strategies show a negative link with some measures of L2 proficiency. Although the significant role of affective strategies has been emphasized by many authors, Oxford's (2003) statement might be the explanation for the results of this study when EFL students reported higher level use of affective strategy category than ESL participants despite their lower English proficiency. Particularly, Oxford (2003) also believes that as some students progress toward higher proficiency, they no longer need affective strategies as much as before. This is also in line with Ehrman et al.'s (2003) opinion when they propose that highly advanced L2 learners who have reached distinguished levels of proficiency tend not to need affective strategies any longer.

Concerning the five most used strategies, the participants of both groups shared the same strategies but there were differences in the order and frequency degree of the strategy use. The high usage level of the strategies by the ESL group reveal that the students of this group were aware of the importance of these strategies and preferred using them during their reading performance.

Anderson (1991) emphasizes that strategic reading is not only a matter of knowing what 
strategy to use, but also the reader must know how to use strategy and orchestrate its use with other strategies, it is not sufficient to know about strategies; a reader must also be able to apply them strategically. However, the results of the study indicate that Orchestrating Strategy Use was one of the five least used strategies by both groups. This means though ESL students showed higher frequency degrees in the strategy use than their counterparts, the students of the both groups were still not very strategic English readers.

\section{Conclusions}

Adolescents entering the adult world in the $21^{\text {st }}$ century read and write more than at any other time in human history (Moore, et al., 1999, p.3). In the full bloom of technology, especially in the stage of the fourth industrial revolution, students' ability to read might be crucial as they will need literacy to cope with the flood of information and to feed their imaginations to create their future. Some important conclusions might be made from this study as follows.

First, the results of this study reveal that motivation of learning English in general and of reading in English in particular might be a key factor for students' reading comprehension success. Many teachers acknowledge that students' lack of motivation causes many of problems they face in teaching (O'Flahavan, et al., 1992). Reading motivation is a multifaceted construct that includes reading goals, intrinsic and extrinsic motivation, selfefficacy and social motivation for reading (Guthrie \& Wigfield, 2000), and it refers to the internal states that make people read (Mazzoni, et al., 1999). Wood et al. (1998) suggests that how a learner views himself as a social being is a crucial determiner of his motivation. Motivation and de-motivation for learning are not simply manifestations of individual cognition but consequences of a complex interaction between the person and the social. Nearly all of the participants in this study identified the significant importance of being a proficient English reader, but not many of them showed high English reading proficiency. Therefore, teachers should certainly help students be aware of the significant role of English reading proficiency and their mission to become proficient English readers, for their university study and their future career. Then teachers might help students identify clearly their English reading goals, both long-termed and short-termed.

Second, reading strategies play positive roles in English reading comprehension as they facilitate learning to read effectively (Anderson, 1991; Carter \& Nunan, 2001; Grabe \& Stoller, 2001; Oxford,1990; Rubin, 2008). University teachers should raise students' awareness of equipping the strategies to help improve their reading competence. Teachers should have a clear understanding of the use of each strategy so that they could not only provide students basic knowledge of various reading strategies but also teach students how to use them effectively as "it is not the presence or absence of a strategy that leads to effective learning; rather it is how that strategy is used (or not used) to accomplish tasks and learner goals" (Rubin, 2008, p. 11).

Third, before conducting strategy instruction, it is necessary for teachers to take a survey to get information about students' strategy use and their demographic data. The questionnaire used in this study might be a good recommendation for teachers as it based on Oxford's (2013) S2R newest theoretical framework with lots of advantages.

Last, the content of the strategy instruction might be a major concern. This study reveals some good strategies that were used frequently by ESL students who self-rated high proficient English readers such as Activating Knowledge, Going Beyond the Immediate Data, Using the Senses to Understand and 
Remember, Reasoning, and Conceptualizing Broadly, etc. Those strategies should be introduced to students, especially to low proficiency English readers. Besides, teachers should also show students how to combine strategies during their reading by introducing Orchestrating Strategy Use. Through reading strategy instruction teachers should help learners construct explicit knowledge about when and where to use appropriate strategies (Goh, 2008) which may enable individuals to plan, monitor, and evaluate their English reading.

\section{References}

Aebersold, J. A., \& Field, M. L. (1997). From Reader to Reading Teacher. Cambridge: Cambridge University Press.

Alvermann, D., \& Earle, J. (2003). Comprehension instruction. In A. P. Sweet \& C. Snow (Eds.), Rethinking reading comprehension (pp. 12-30). New York: Guilford Press.

Anderson, N. J. (1991). Individual differences in strategy use in second language reading and testing. Modern Language Journal, 75, 460-472.

Anderson, N. J. (2003). Scrolling, clicking, and reading English online reading strategies in a second/ foreign language. The Reading Matrix, 3(3), 1-33.

Andres, V. (2002). The Infuence of Affective Variables on EFL/ESL Learning and Teaching. The Journal of the Imagination in Language Learning and Teaching, 7. Retrieved from http://www.njcu.edu/ CILL/vol7/andres.html

Arnold, J. \& Brown, H.D. (1999). A map of the terrain. In J. Arnold (Ed.), Affect in Language Learning (pp. 1-24). Cambridge: Cambridge University Press.

Auerbach, E., \& Paxton, D. (1997). "It's not the English thing": Bringing reading research into the ESL classroom. TESOL Quarterly, 31, 237-261.

Baker, L., \& Wigfield, A. (1999). Dimensions of children's motivation for reading and their relations to reading activity and reading. Reading Research Quarterly, 34, 452-477.

Baumann, J. F., \& Duffy, A. M. (1997). Engaged Reading for Pleasure and Learning: A Report from the National Reading Research Center. National Reading Research Center (NRRC).

Brown, A. L. (1980). Metacognitive development and reading. In R.J.Spiro, B.C. Bruce, \& W.E.Brewer (Eds.), Theoretical issues in reading comprehension. Perspective from cognitive psychology, linguistics, artificial intelligence, and education (pp. 453-481). Hillsdale, NJ, Erlbaum.
Carter.R., D Nunan, D. (Eds). (2001). The Cambridge Guide to Teaching English to Speakers of Other Languages. Cambridge University Press.

DeMoulin \& Loye (1999). Helping children to learn to read. Education, 120(1), 40-43.

Dreyer, C. \& Nel.C. (2003). Teaching reading strategies and reading comprehension within a technologyenhanced learning environment. System 31, 349365.

Durkin, D. (1993). Teaching them to read (6th Ed.). Boston: Allyn \& Bacon.

Ehrman, M.E., Leaver, B.L., Oxford, R.L. (2003). A Brief Overview of Individual Differences in Second Language Learning, System 31.

Goh, C. (2008). Metacognitive instruction for second language listening development: Theory, practice and research implications. RELC Journal, 39(2), 188-213.

Grabe, W., \& Stoller, F. L. (2001). Reading for academic purposes: Guidelines for the ESL/EFL teacher. In M. Celce-Murcia (Ed.), Teaching English as a second or foreign language (3rd ed.) (pp.187-203). Boston, MA: Heinle \& Heinle.

Guthrie, J.T., Wigfield, A. (2000). Engagement and motivation in reading. In M.L Kamil, P.B Mosenthal, P.D. Pearson, \& R. Barr (Eds.), Handbook of reading research (3rd ed.) (pp. 403-422). New York, NY: Longman.

Guthrie, J. T., Wigfield, A., \& VonSecker, C. (2000). Effects of integrated instruction on motivation and strategy use in reading. Journal of Educational Psychology, 92, 331-341.

Hsu, Li-W. (2008). Taiwanese Hospitality College Students' English Reading Strategies in English for Specific Purpose Courses. Journal of Hospitality and Home Economics, 5(1), 53-67.

Karbalaei, A. (2010). AComparison of the Metacognitive Reading Strategies Used by EFL and ESL Readers. The Reading Matrix, 10(2), 165-180.

Kaylani, C. (1996). The influence of gender and motivationon EFL learning: Strategy used in Jordan. In R.L.Oxford (Ed.), Language learning strategies around the world. Cross culturalperspectives. Manao: University of Hawaii Press.

Magno, C. (2009). Self-regulation and approaches to learning in composition writing in English. TESOL Journal, 1, 1-16.

Mazzoni, S. A., Gambrall, L. B. \& Kokeamaki, R. L. (1999). A cross cultural perspective of early literacy motivation. Journal of Reading Psychology, 20.

McDonough, J. and Shaw, C. (2013). Materials and Methods in ELT: A Teacher's Guide (3rd edition). Oxford: Blackwell.

Mikulecky, B. S. (2008). Teaching Reading in a Second Language. Pearson Education, Inc.

Moore, D. W., Bean, T. W., Birdyshaw, D., \& Rycik, J. A. (1999). Adolescent literacy: A position statement 
for the commission on adolescent literacy of the International Reading Association. International Reading Association.

O’Flahavan, Winsor, P., Nagy, W. E., Osborn, J. (1992). Guidelines for Instruction in Structural Analysis. Technical Report No. 554. College of Education. University of Illinois at Urbana-Champaign.

Oxford, R. L. (1990). Language Learning Strategies. What Every Teacher should know. Boston: Heinle \& Heinle Publishers.

Oxford, R. L. (2001). Language learning strategies. In R. Carter \& D. Nunan (Eds.), The Cambridge guide to teaching English to speakers of other language (pp.166-172). Cambridge: Cambridge University Press.

Oxford, R.L. (2003). Language Learning Styles and Strategies: An Overview. Learning Styles \&
Strategies/ Oxford, GALA 2003.

Oxford, R.L. (2013). Teaching and researching language learning stratgies. Pearson. Harlow. UK.

Rubin, J. (2008). Reflections. In C. Griffiths (Ed.), Lessons from good language learners (pp. 1015). Cambridge: Cambridge University Press. doi:10.1017/ CBO9780511497667.

Tercanlioglu, L. (2004). Postgraduate students' use of reading strategies in L1 and ESL contexts: Link to success. International Education Journal, 5/4. Retrieved on August 17, 2006, from http:// ehlt.flinders.eduau/education/iej/articles/v5n4/ tercanlioglu/paper.pdf

Wood, E., Motz, M., \& Willoughby, T. (1998). Examining students' retrospective memories of strategy development. Journal of Educational Psychology, 90, 698-704.

\title{
CHIẾN LƯợC ĐỌC TIẾNG ANH CỦA SINH VIÊN HỌC TIẾNG ANH NHU' MỘT MÔN HỌC BẮT BUỘC VÀ SINH VIÊN SỦ DỤNG TIẾNG ANH NHU' PHƯƠNG TIỆN HỌC TẬP
}

\author{
Nguyễn Thị Bích Thủy \\ Truờng Cao đẳng Kinh tế - Kỹ thuật Thưong mại, Phú Lãm, Hà Đông, Hà Nội, Việt Nam
}

Tóm tắt: Đọc hiểu là một trong những yếu tố quan trọng nhất của việc học tiếng Anh đối với sinh viên, bởi nó là nền tảng cung cấp kiến thức trong mọi lĩnh vực học ngôn ngữ (Mikulecky, 2008). Sự lĩnh hội được tăng cường khi người đọc tích cực sử dụng các chiến lược phù hợp trong quá trình đọc (Brown, 1980). Bài viết này nhằm tìm hiểu liệu có sự khác biệt nào trong việc sử dụng chiến lược khi đọc văn bản tiếng Anh thông dụng giữa sinh viên Việt Nam học tiếng Anh như một môn bắt buộc (sinh viên $\mathrm{EFL}$ ) và những sinh viên sử dụng tiếng Anh như phương tiện học tập (sinh viên ESL).

Từ khóa: đọc, đọc hiểu, đọc sách, học sinh EFL và ESL 


\section{APPENDIX \\ QUESTIONNAIRE ON STUDENTS' STRATEGY USE IN READING COMPREHENSION (For Reading General English texts)}

In order to assess the use of English reading strategies of students, please answer the following questions by filling in the personal information and marking $\mathrm{X}$ with the appropriate choices. The information obtained is for research purposes only.

\section{Part I: Personal Information}

1. Full name: Age:

2. Gender: Male $\square \quad$ Female $\square \quad$ 4. Major:

5. Freshmen, Sophomore, Junior, or Senior (circle one)

6. How long have you been studying English?

7. Do you like learning English? Yes $\square$

Do not mind

8. Do you like reading in English? Yes

No

Do not mind

9. Have you ever been trained about reading strategies? Yes

No

10. How do you rate your overall English proficiency?
Very Good
Good
Fair
Poor $\square$

11. How do you rate your English reading proficiency?
Very Good
Good $\square$
Fair
Poor $\square$

12. How important is it for you to become proficient in reading in English?
Very important $\square$ Important
Not so important
Not important

\section{Part II: Reading Strategy Use}

This questionnaire has been designed to help you to identify which strategies you use in reading comprehension.

Read each statement below. Please write the respond 1, 2, 3, 4, or 5 that tells HOW TRUE OF YOU THE STATEMENT IS.

1. Never or almost true of me

2. Usually not true of me

3. Somewhat true of me

4. Usually true of me

5. Always true of me

(1) means that the statement is very rarely true of you

(2) means that the statement is true less than half the time

(3) means that the statement is true of you about half the time

(4) means that the statement is true more than half the time

(5) means that the statement is true of you almost always

Mark an $X$ in the appropriate column.

Please respond to each statement quickly, without too much thought. Try not to change your responses after you choose them. Please use a pen to mark your choices. 
Example:

\begin{tabular}{|c|c|c|c|c|c|c|}
\hline No. & Statements & $\mathbf{1}$ & $\mathbf{2}$ & $\mathbf{3}$ & $\mathbf{4}$ & $\mathbf{5}$ \\
\hline 1 & I focus on the text when reading. & (1) & (2)X & (3) & (4) & (5) \\
\hline
\end{tabular}

\section{Questionnaire statements}

\begin{tabular}{|c|c|c|c|c|c|c|}
\hline No. & Statements & 1 & 2 & 3 & 4 & 5 \\
\hline \multicolumn{7}{|c|}{ METASTRATEGIES } \\
\hline 1 & I focus on the text when reading. & (1) & (2) & (3) & (4) & (5) \\
\hline 2 & I plan for reading. & (1) & (2) & (3) & (4) & (5) \\
\hline 3 & $\begin{array}{l}\text { I use references (dictionaries, vocabulary, etc.) to help me } \\
\text { understand what I need to read. }\end{array}$ & (1) & (2) & (3) & (4) & (5) \\
\hline 4 & I organize reading to get effectiveness. & (1) & (2) & (3) & (4) & (5) \\
\hline 5 & I implement the reading plans. & (1) & (2) & (3) & (4) & (5) \\
\hline 6 & I Orchestrate the strategy use when reading. & (1) & (2) & (3) & (4) & (5) \\
\hline 7 & I monitor my reading. & (1) & (2) & (3) & (4) & (5) \\
\hline 8 & I evaluate my reading. & (1) & (2) & (3) & (4) & (5) \\
\hline \multicolumn{7}{|c|}{ COGNITIVE STRATEGIES } \\
\hline 9 & I use the senses to understand and remember what I read. & (1) & (2) & (3) & (4) & (5) \\
\hline 10 & I activate my knowledge to understand the reading text. & (1) & (2) & (3) & (4) & (5) \\
\hline 11 & $\begin{array}{l}\text { I reason (analyze and guess grammatical points, vocabulary, etc.) } \\
\text { what I read to understand the text (Reasoning). }\end{array}$ & (1) & (2) & (3) & (4) & (5) \\
\hline 12 & $\begin{array}{l}\text { I guess new words or phrases while reading through the analysis } \\
\text { of known elements (Conceptualizing with Details). }\end{array}$ & (1) & (2) & (3) & (4) & (5) \\
\hline 13 & $\begin{array}{l}\text { I guess the text based on the link between words, phrases, } \\
\text { concepts, etc., in the reading (Conceptualizing Broadly). }\end{array}$ & (1) & (2) & (3) & (4) & (5) \\
\hline 14 & $\begin{array}{l}\text { I deduce the content of the readings from the available } \\
\text { information (title, known vocabulary, topic sentences ...) (Going } \\
\text { Beyond the Immediate Data). }\end{array}$ & (1) & (2) & (3) & (4) & (5) \\
\hline \multicolumn{7}{|c|}{ AFFECTIVE STRATEGIES } \\
\hline 15 & $\begin{array}{l}\text { I am self-motivated in the process of reading through activating } \\
\text { supportive emotions, beliefs, and attitudes. }\end{array}$ & (1) & (2) & (3) & (4) & (5) \\
\hline 16 & I generate and maintain motivation when reading. & (1) & (2) & (3) & (4) & (5) \\
\hline \multicolumn{7}{|c|}{ SOCIOCULTURAL- INTERACTIVE STRATEGIES } \\
\hline 17 & I interact with others while reading to learn and communicate. & (1) & (2) & (3) & (4) & (5) \\
\hline 18 & $\begin{array}{l}\text { I overcome knowledge gaps about the text in communicating } \\
\text { with others. }\end{array}$ & (1) & (2) & (3) & (4) & (5) \\
\hline 19 & $\begin{array}{l}\text { I try to deal with sociocultural contexts and identities when } \\
\text { reading. }\end{array}$ & (1) & (2) & (3) & (4) & (5) \\
\hline
\end{tabular}

Thank you for your cooperation! 